\section{Estudo \\ CoDebate}

em Testão

Plamejamento
Revista Estudo \& Debate, Lajeado, v. 23, n. 2, 2016. ISSN 1983-036X

DOI: http://dx.doi.org/10.22410/issn.1983-036X.v23i2a2016.1137

\title{
PROPOSTAS DE DIRETRIZES DE GESTÁO AMBIENTAL PARA O CAMPO PETROLÍFERO CANTO DO AMARO, RN, BRASIL
}

\author{
Jorge Luis de Oliveira Pinto Filho ${ }^{1}$, Reinaldo Antonio Petta ${ }^{2}$
}

\begin{abstract}
Resumo: Este artigo tem por objetivo elaborar propostas de diretrizes de gestão ambiental para o Campo Petrolífero Canto do Amaro, RN, Brasil - CPCA/RN. Para condução deste trabalho utilizou-se o conceito de gestão ambiental definido por Santos (2004), sendo composto por: diagnóstico ambiental, planejamento ambiental e gerenciaemento ambiental. Nesta perspectiva, os procedimentos metodológicos seguiram as seguintes fases: Fase 01 - Diagnóstico Ambiental; Fase 02 - Planejamento Ambiental e; Fase 03 - Gerenciamento Ambiental. Observou-se que as atividades desenvolvidas no CPCA/RN podem gerar efeitos adversos que se relacionam com os compartimentos ambientais; os aspectos sociais e; os circuitos econômicos, tornando essa área de vulnerabilidade e riscos. Portanto, para atenuar a problemática da área investigada faz-se necessário adotar planos, programas e projetos que visem o controle da poluição ambiental; a promoçáo e inclusão das comunidades tradicionais e; a melhoria contínua da eficiência econômica do processo produtivo.
\end{abstract}

Palavras-chave: Indústria do Petróleo. Aspectos e Impactos Ambientais. Planejamento e Gestão Ambiental. Sustentabilidade.

\section{PROPOSALS OF ENVIRONMENTAL MANAGEMENT GUIDELINES FOR THE OILFIELD CANTO DO AMARO, RN, BRAZIL}

\begin{abstract}
This article aims to draw up proposals for environmental management guidelines for the Oilfield Canto do Amaro, RN, Brazil - CPCA / RN. In order to carry out this work, we used the concept of environmental management defined by Santos (2004), consisting of: environmental assessment, environmental planning and environmental management. From this perspective, the methodological procedures followed the following stages: Stage 01 - Environmental Diagnosis; Phase 02 - Environmental Planning; Stage 03 - Environmental Management. It was observed that the activities developed in the CPCA / RN may have adverse effects which relate to the environmental compartments; the social aspects and; the economic circuits, making this area of
\end{abstract}

1 Doutorando em Desenvolvimento e Meio Ambiente pela Universidade Federal do Rio Grande do Norte UFRN com 1 ano de doutorado-sanduíche na Technische Universität Bergakademie Freiberg, Alemanha. Professor Assistente I na Universidade Federal Rural do Semi-Árido - UFERSA, Campus Pau dos Ferros. E-Mail: jorge.filho@ufersa.edu.br

2 Doutor em Geoquímica pela Universidade Estadual Paulista Júlio de Mesquita Filho - UNESP com 2 anos de doutorado-sanduíche na Universidade Católica Louvain, Bélgica. Professor Titular da Universidade Federal do Rio Grande do Norte - UFRN, Departamento de Geologia, Laboratório de Geomática LAGEOMA; Campus Universitário - Natal (RN). E-mail: petta@ccet.ufrn.br 
vulnerability and risk. Therefore, to mitigate the problems of the investigated area makes it necessary to adopt plans, programs and projects aimed at controlling environmental pollution; the promotion and inclusion of traditional communities and; the continuous improvement of economic efficiency of the productive process.

Keywords: Petroleum Industry; Environmental Aspects and Impacts; Planning and Environmental Management; Sustainability.

\section{INTRODUÇÁO}

O baixo curso da Bacia Hidrográfica do Rio Apodi-Mossoró - BHRAM, localizado na Região Oeste do Estado do Rio Grande do Norte, contempla uma enorme interferência de açóes antrópicas, com foco para atividade salineira, carcinicultura, pesca predatória, turismo, geração de energia eólica, urbanização e, exploração de petróleo e gás natural.

O desenvolvimento da atividade petrolífera nessa regiáo ocorre principalmente no Campo Petrolífero Canto do Amaro - CPCA, que foi descoberto em 1985, estando localizado entre os municípios de Mossoró e Areia Branca, com reserva de 116 milhóes de barris de óleo (MILANI E ARAÚJO, 2003), onde no ano de 2014 operou com 1.109 poços de petróleo e/ou gás (PORTAL BRASIL, 2014).

A infraestrutura de exploração do CPCA/RN em funcionamento desde 1986 (PORTAL BRASIL, 2014), contemplando as etapas de: prospecção; avaliação de formação; exploração; perfuração; completação; elevação e; produção (THOMAS, 2004), tornandose um importante setor econômico para o desenvolvimento regional da regiáo.

Apesar da importância econômica do CPCA/RN nessa área os problemas socioambientais oriundos da atividade petrolífera ocorrem com frequência, sendo temática nos estudos de Barbosa, Souza Neto e Silva Filho (2007); Oliveira e Santos (2007); Costa Filho, Barbosa e Petta (2008); Costa Filho et al. (2009); Costa Filho, Barbosa e Petta (2010); Medeiros, Cunha e Almeida (2011); Correia e Jerônimo (2012); Petta e Campos (2013); Meneses e Paula (2014) e; Oliveira e Jerônimo (2014).

Com base nos autores citados anteriormente, os principais impactos ambientais na área do CPCA/RN estão relacionados com geração de emissóes atmosféricas, resíduos sólidos e semissólidos, efluentes líquidos e ruídos; poluição hídrica, terrestre, sonora, atmosférica e visual; supressão vegetal; processos erosivos; interferência na flora e fauna; alteração nos ecossistemas e na dinâmica de uso do solo; pressão nas comunidades locais; interferências nas atividades tradicionais; pressão nos serviços públicos; pressão na estrutura de exploração de petróleo e gás e; tráfego de veículos. É oportuno destacar a possibilidade de geração de riscos, com destaque para: riscos à saúde dos trabalhadores; riscos de incêndios; riscos de acidentes e; riscos de explosóes. Além disso, tem o potencial de ocorrência de acidentes relacionados com: as instalaçóes elétricas por causa da insegurança; rompimento nas caixetas dos cavalos de pau através rompimento; nas cerca de proteção devido à falta de sinalização; nas linhas de de produção em virtude da deficiência de manutenção; nas estradas por precariedades; nos cavaletes de sustentação de tubos deteriorados. Entretanto, estes estudos não estabelecem açóes para atenuar os impactos, os riscos e os acidentes dessa atividade econômica pesquisada. 
Nesta perspectiva, faz-se necessário elaborar mecanismos que atuem para prevenir e/ou controlar os impactos socioambientais da referida área de estudo permintindo assim a possibilidade de diminução dos conflitos socioais, econômicos, ambientais, políticos, territoriais e, saúde pública.

Assim, a redução dos conflitos do CPCA/RN, se efetuará através de um planejamento e gestão ambiental das atividades, processos e serviços desenvolvido na área, uma vez que entende-se por Gestão Ambiental como o processo que inclui o planejamento, o monitoramento, o licenciamento, a fiscalizaçáo e a administração, destinados ao cumprimento dos padrốes de qualidade ambiental e a incorporaçấo da dimensão ambiental, economia e social, levados a cabo por meio de uma ampla gama de instrumentos administrativos, econômicos e legais (PORTO E SCHÜTZ, 2012).

A abordagem de estudos sobre planejamento e gestáo ambiental voltados para atividades econômicas vem sendo debatida por: Conyers e Hills (1984); Friedmann (1987); Slocombe (1993); Santos e Pivello (1998); Lagrotti (2000); Young (2000); Fidalgo (2003) e; Santos (2004). Em termos da atividade petrolífera evidencia que tais estudos ainda ocorrem de forma tímida, tornando-se uma necessidade de tal processo para assegurar a eficiência econômica, justiça social e prudência ecológica dessa atividade econômica.

Portanto, objetiva-se com este estudo elaborar açóes de planejamento e gestáo ambiental do CPCA/RN.

\section{MATERIAL E MÉTODOS}

\subsection{Delimitação e descriçáo da área de estudo}

O CPCA/RN está localizado entre os municípios de Mossoró e Areia Branca (FIGURA 01), a cerca de $260 \mathrm{~km}$ de Natal e $20 \mathrm{~km}$ da cidade de Mossoró. Situa-se na parte nordeste da Bacia Potiguar emersa, sobre um alto estrutural denominado de "Alto de Mossoró", adjacente à "linha de charneira" de Areia Branca, numa área requerida de aproximadamente, $362,791 \mathrm{~km}^{2}$ (ANP, 2009) (FIGURA 01). 
Figura 01 - Localizaçâo do Campo Petrolífero Canto do Amaro - CPCA/RN, 2009

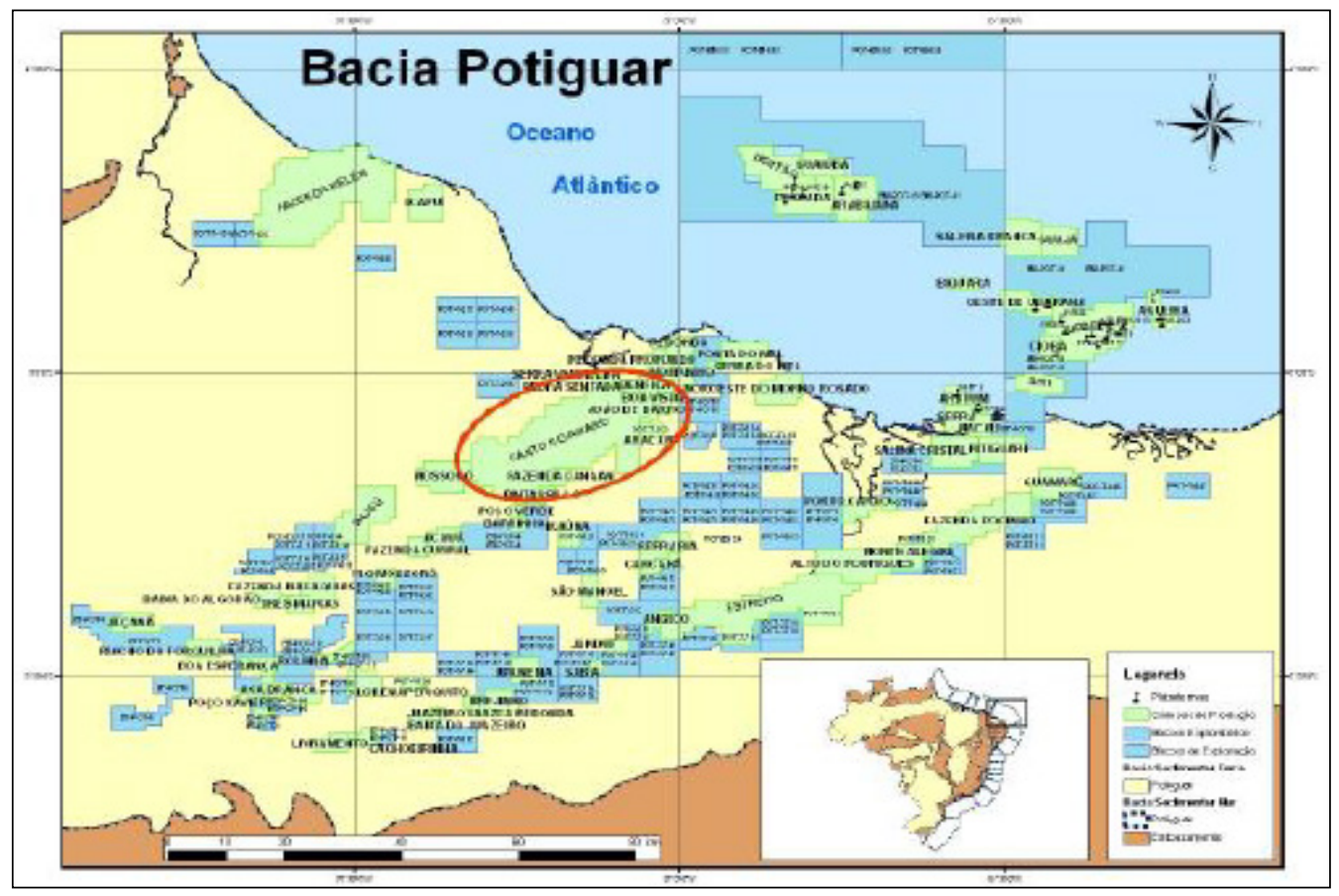

Fonte: ANP (2009).

A descoberta deste campo petrolífero ocorreu em novembro de 1985, pelo poço 1- CAM-1-RN, o qual encontrou óleo nos arenitos da Formação Açu, de idade cretácica (ANP, 2009), com início da exloraçáo no ano seguinte, com uma reserva de 116 milhões de barris de óleo (MILANI E ARAÚJO, 2003).

A cadeia produtiva do petróleo é organizada nas fases Upstream (exploração, perfuração e produção), Midstream (refinamento) e Downstream (transporte, distribuição e comercialização) (THOMAS, 2004). Neste trabalho enfatizou-se a fase Upstream que contempla as atividades do CPCA/RN (prospecção; avaliação de formação; exploração; perfuração; completação; elevação e; produção).

Esta regiāo de maior produção nacional de petróleo em terra, composta por 1.109 poços de petróleo e gás (PORTAL BRASIL, 2014) vem sendo explorada em uma considerável infraestrutura de exploração e transporte de óleo e/ou gás (cavaletes de sustentação; central de tratamento dos cascalhos de perfuração; cisternas de proteção; dutos; estação de tratamento de efluentes; estação de tratamento de óleo; estaçôes coletoras de óleo; estaçóes de bombeamento; estaçóes receptoras de óleo; estradas; incineradores; jazidas de mineração de areia; lagoas de tratamento; linhas de produção; linhas de surgências; linhas de vapor com $70^{\circ} \mathrm{C}$; linhas elétricas de alta tensão; poços de injecção; poços de petróleo; sondas de perfuração e; veículos de transportes de óleo). 


\subsection{Fundamentação teórica e metodológica}

A pesquisa classifica-se conforme sua finalidade em descritiva (descreve as características de dada população ou fenômeno em estudo) e, exploratória (torna o problema mais explícito). Quanto aos meios utilizados, enquadra-se estudo bibliográfico (levantamento de informações da área de estudo) e pesquisa de campo, através do levantamento de impactos ambientais do CPCA/RN para propor açóes de gestão ambiental (GIL, 2006).

Para Santos (2004) gestão ambiental é entendida como uma integração entre a diagnóstico ambiental (conhecimento da realidade); planejamento ambiental (elaboração de propostas para consolidação e/ou alteração parcial e/ou total da realidade) e; gerenciamento ambiental (monitoramento das propostas).

A proposição de açóes de gestão ambiental para o CPCA/RN baseado em Santos (2004) se deu com coleta de dados da seguinte forma: fase 01 - diagnóstico ambiental (levantamento teórico da caracterização da área, descrição do processo produtivo da atividade econômica, identificação dos impactos ambientais e, descrição das ações desenvolvidas); fase 02 - planejamento ambiental (levantamento das açóes de gestáo ambiental para atenuar os impactos ambientais determinados na fase anterior); e; fase 03 - gerenciamento ambiental (propor aspectos de monitoramento das ações de gestão ambiental).

\section{Fase 01 - Diagnóstico Ambiental}

A Fase 01 - Diagnóstico Ambiental consiste no reconhecimento da realidade atual da área investigada, para isso é composta por três etapas sequenciais: Etapa 01 - inventário; Etapa 02 - reconhecimento da área; Etapa 03 - identificação dos impactos ambientais e; Etapa 04 - ações de gestão ambiental desenvolvidas na área investigada.

\section{Etapa 01 - Inventário}

$\mathrm{O}$ inventário do CPCA/RN consiste na sua caracterização, através de levantamento de dados secundários junto aos órgãos oficiais das características: política; socioeconômicas e físico-ambientais da região. Para concretização desta etapa realizou-se coleta dos dados dos municípios de Mossoró e Areia Branca, onde fica situado o campo de petróleo investigado, utilizando como base os resultados: do CPRM (2005) para economia, geologia, vegetação e recursos hídricos; do IDEMA do ano de (2008) para fundação dos municípios, clima e solos; do Instituto Brasileiro de Geografia e Estatística - IBGE (2010) para os aspectos sociais.

\section{Etapa 02 - Visita de Reconhecimento da Área de Estudo}

Durante, o período de 07 a 11 de Outubro de 2015, realizaram visitas no CPCA/ RN para identificar o processo produtivo da atividade petrolífera nessa área investigada, a partir da definição de Thomas (2004), que contempla as etapas: prospecçáo; avaliação de formação; exploração; perfuração; complementação; elevação e; produção.

\section{Etapa 03 - Identificaçáo dos Impactos Ambientais}

Nessa fase são identificados os aspectos e impactos ambientais em função das atividades, processos e produtos desenvolvidos na área de exploração de petróleo do CPCA/ RN. Assim, com auxílio do método de Avaliação de Impactos Ambientais - AIA checklist determinou-se os impactos ambientais na área de estudo levando em consideração os 
aspectos ambientais, econômicos e sociais com relação ao processo produtivo (SÁNCHEZ, 2012).

A escolha dessa ferramenta deve-se ao fato de ser considerado um método rápido e conciso (SÁNCHEZ, 2012), onde utilizou como base as variáveis de: localização da área de estudo; localização dos usuários dos recursos naturais; tipos de usos dos recursos naturais; possíveis fontes potenciais ou efetivamente poluidoras da área de estudo; efeitos da poluição ambiental e técnicas de controle da poluição ambiental (DERÍSIO, 2012).

Os dados primários e secundários obtidos foram expostos em um primeiro momento através de uma tabela para correlacionar as principais leis ambientais e outras normas aplicadas para o controle e gerenciamento dos respectivos impactos ambientais e, em um segundo momento por meio de de uma matriz de interação (SÁNCHEZ, 2012).

\section{Etapa 04 - Açóes de gestáo ambiental desenvolvidas}

Por fim, na fase de diagnóstico ambiental da área investigou-se as ações ambientais desenvolvidas na área de estudo visando atenuação da problemática junto à órgãos ambientais federal, estadual e municipal; as empresas atuantes na área e; outras instituições por meio de dados secundários dessas representaçóes.

\section{Fase 02 - Planejamento Ambiental}

A Fase 02 - Planejamento Ambiental tem por finalidade a elaboração de propostas para consolidação e/ou alteração parcial e/ou total da realidade visando atingir a gestão ambiental da área investigada.

O conceito de planejamento vem sendo discutido corriqueiramente no meio científico, apresentando definiçóes com enfoque em diversas variáveis. Para Friedmann (1987), planejamento corresponde à coleta e análise de informaçóes disponibilizadas a serviço do interesse público, com a finalidade de direcionar as diversas atividades econômicas e o desenvolvimento social. Aliando a este conceito observou-se também a abordagem de Conyers e Hills (1984), onde o planejamento corresponde à escolha de alternativas acerca da utilização dos recursos disponíveis, visando ao cumprimento de metas específicas dentro de um determinado prazo. Corroborando tal pensamento, Fidalgo (2003) refere-se às metas e aos objetivos como sendo a expressão das prioridades do planejamento.

Além desses fatores, o planejamento ambiental deve levar em consideração aspectos sobre área, escala e temporalidade. Para Santos e Pivello (1998) a definição da unidade de trabalho deve iniciar com a compreensão das interaçóes e pressóes sobre os sistemas naturais ou antrópicos a serem estudados; com isso, a delimentação da área de estudo deste artigo consiste no CPCA/RN e as comunidades rurais circunvizinhas. Em termos de escala, o estudo focou o baixo curso do rio do Carmo, principal tributário do Rio Apodi-Mossoró, ou seja, será uma micro-bacia adotada como unidade investigada; tendo em vista que diversos estudos vêm utilizando a micro-bacia como escala, como por exemplo, Young (2000) e Lagrotti (2000), devido ser uma unidade geográfica natural e possibilita a identificação de fatores socioeconômicos e ambientais homogêneos. Quanto à temporalidade, Santos (2004) afirma que é representada por meio da construção de cenários: o cenário passado (o que foi), o cenário real (o que é) e o cenário futuro (o que será); assim, construiu-se uma 
proposta com base na realidade atual, onde buscará o desenvolvimento de ações projetar um novo cenário da área.

Dentro de uma perspectiva holística, Slocombe (1993) evidencia que planejamento ambiental enfoca o ambiente biofísico onde vivem as pessoas e comunidades, analisa os efeitos de atividades de desenvolvimento, por um processo baseado em metas, planos e regulamentos. Assim, para elaborar o planejamento ambiental, Santos (2004) enfatiza que deve ter a adequação de açóes à potencialidade, vocação local e à capacidade de suporte, através do desenvolvimento harmônico da região e a manutenção da qualidade do ambiente físico, biológico e social.

Diante das definiçóes expostas, pode configurar que abordagem de planejamento ambiental utilizada neste trabalho, evidencia que se trata de um processo, que inclui: objetivo, ação, responsabilidade, meta e prazo, por meio da atenuação da problemática socioeconômica e ambiental da região.

\section{Fase 03 - Gerenciamento Ambiental}

Para garantir o acompanhamento das açóes propostas na fase anterior, realizouse a proposição de aspectos de gerenciamento ambiental com finalidade da avaliação da eficiência e/ou a eficácia das açóes, que deverão ser implementadas a curto, médio e longo prazo, onde envolve os critérios de: etapas, monitoramento, indicadores e, responsável pela análise.

\section{RESULTADOS E DISCUSSÃO}

\subsection{Diagnóstico socioambiental e econômico do CPCA/RN}

O diagnóstico socioambiental e econômico do CPCA/RN, consiste em um processo sistemático que envolve inicialmente o levantamento dos impactos ambientais e; posteriormente a identificação das açóes de gestão ambiental desenvolvidas.

\subsubsection{Identificação dos impactos ambientais da área de estudo}

Para subsidiar a identificação dos impactos ambientais na área do CPCA/RN determinaram-se as atividades, processos e produtos nesse campo de petróleo. Com isso, enfatizou-se a fase Upstream que contempla as fases: prospecção; avaliação de formação; exploração; perfuração; completação; elevação e; produção.

$\mathrm{Na}$ área do CPCA/RN a fase de prospecção é composta pelas etapas: permissória, elaboração de croqui da área, estudos geodésicos, abertura e nivelamento da área, perfuração da área, carregamento, tamponamento, espalhamento de material, detonação, recolhimento de material, oficinas de cabos e recuperação da área. $\mathrm{Na}$ fase de avaliação de formação dos reservatórios de petróleo encontram-se as etapas de perfilagem a poço aberto, testes de pressão a poço revestido e perfilagem de produção. Para exploração de petróleo são adotadas as etapas de construçáo da base, operação de Desmontagem Transporte e Montagem DTM e perfuração do poço. A perfuração de poço ocorre com construção de acessos, construção da base do poço, intervenção da sonda de perfuração, instalaçóes de tanques de 
testes para poços exploratórios, instalação de linha de surgência e avaliação da capacidade de produção para poços exploratórios. $\mathrm{Na}$ adequação dos poços de petróleo é executada a fase de completação, com ações de circulação de fluido, uso de máquinas de combustão interna, correção de cimentação montagem do canhão e completação. Para tornar o CPCA/ RN apropriado para produção inicia-se a fase de elevação, através de instalação, operação e manutenção do bombeio mecânico com hastes; instalação do poço de injeção e descartes dos fluídos do poço de injeção. Finalmente, a produção no CPCA/RN ocorre a partir das etapas de processamento primário, coleta, transporte, armazenamento e distribuição do petróleo para refino.

A fase de prospecção do CPCA/RN tem como impactos positivos a geração de emprego e renda; enquanto observam-se também impactos ambientais negativos, nas atividades de abertura e nivelamento da área, perfuração da área e detonação, com as emissôes atmosféricas veiculares e geração de ruídos (QUADRO 01).

$\mathrm{Na}$ fase de Avaliação da Formação observa-se a geração de emprego e renda com fatores positivos (sem uso de mão de obra local). Os impactos adversos significativos das etapas desse processo são interferências no meio a partir da geração de resíduos sólidos e remoção da cobertura do solo através desmatamento (QUADRO 01).

A fase de Exploração do CPCA/RN os benefícios referem-se a geração de royalties e a maior possibilidade da utilização da mão de obra local. Os impactos ambientais negativos mais significativos são a alteração das propriedades do solo a partir da geração de lama e cascalho e alteração dos compartimentos ambientais (QUADRO 01).

A fase de Perfuração do CPCA/RN constatam-se efeitos benéficos na geração de royalties, emprego e renda (utilização da mão de obra local no estabelecimento dos poços). Evidenciam-se alteraçôes nos compartimento ambientais (solo, ar, água e biota) com a geração de ruídos e a geração de fluídos sendo os impactos mais significativos (QUADRO 01).

$\mathrm{Na}$ fase de Completação do CPCA/RN evidenciam-se a geração de royalties, a geração de renda e emprego (utilizou-se de mão de obra local em todas as etapas). Porém, constatam-se efeitos maléficos mais significativos dessa fase nos sistemas ambientais, com a geração de efluentes líquidos e degradação do solo (QUADRO 01).

A fase de Elevação no CPCA/RN oportuniza a geração de royalties, geração de emprego e renda, incluindo a mão de obra local. Essa fase proporciona alteraçóes nos meios físicos, bióticos e antrópicos, principalmente na instalação do bombeio mecânico com hastes com a supressão vegetal e erosão como sendo os impactos mais significativos (QUADRO 01).

$\mathrm{Na}$ fase de Produção no CPCA/RN proporciona os benefícios de geração de royalties, emprego (incluindo mão de obra local), renda, energia e combustível, e projeção da região no cenário nacional. Todavia, no processamento primário, coleta, transporte, armazenamento e, distribuição do petróleo provocam alteraçóes negativas significativas nos compartimentos ambientais e no meio antrópico (QUADRO 01). 
Quadro 1 - Indicadores de Aspectos e Impactos no CPCA/RN

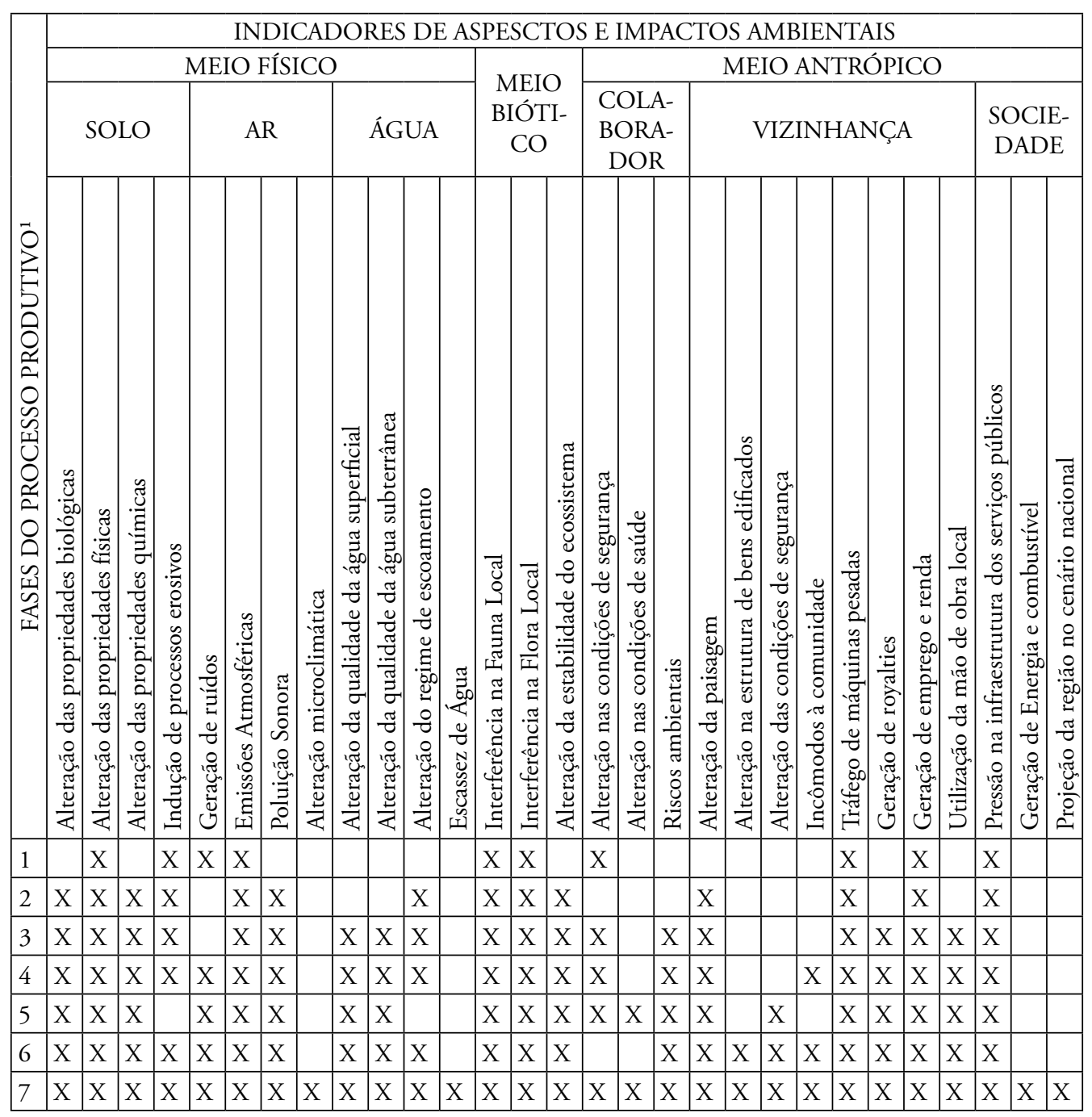

${ }^{1}$ Fases do CPCA/RN: 1- Prospecção, 2- Avaliação de formação, 3- Exploração, 4- Perfuração, 5- Completação, 6- Elevação e, 7- Produção.

A partir da identificação dos impactos ambientais no CPCA/RN apresenta-se uma correlação entre aspectos e impactos ambientais com os requisitos legais aplicados para indústria petrolífera (TABELA 01). 
Tabela 01 - Aspectos e Impactos Ambientais da Cadeia Produtiva do CPCA/RN

\begin{tabular}{|c|c|c|}
\hline FASE & $\begin{array}{l}\text { ASPECTOS E IMPACTOS AMBIEN- } \\
\text { TAIS }\end{array}$ & REQUISITOS LEGAIS APLICADOS \\
\hline \multirow{5}{*}{ Prospecçáo } & Desmatamento & Lei ${ }^{\circ} 9.604 / 1998$ \\
\hline & Erosão & Decreto ${ }^{\circ} 76.470 / 1975$ \\
\hline & $\begin{array}{l}\text { Geração de resíduos sólidos e efluentes } \\
\text { líquidos }\end{array}$ & 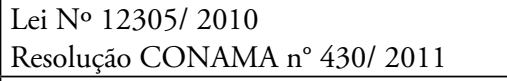 \\
\hline & Poluição do ar por emissóes atmosféricas & $\begin{array}{l}\text { Portaria IBAMA n } 348 \text { de 14/03/1990 } \\
\text { PRONAR } \\
\text { Resolução CONAMA no 5/1989 }\end{array}$ \\
\hline & Geração de emprego e renda & Não aplicável \\
\hline \multirow{6}{*}{$\begin{array}{l}\text { Avaliação da } \\
\text { Formação }\end{array}$} & Afugentamento da fauna & Lei ${ }^{\circ} 9.604 / 1998$ \\
\hline & Desmatamento & Lei ${ }^{\circ} 12.651 / 2012$ \\
\hline & Remoção da cobertura do solo & Decreto ${ }^{\circ} 76.470 / 1975$ \\
\hline & $\begin{array}{l}\text { Geraçáo de resíduos sólidos e efluentes } \\
\text { líquidos }\end{array}$ & $\begin{array}{l}\text { Lei No } 12305 \text { / } \\
\text { Resolução CONAMA n 430/ } 2011\end{array}$ \\
\hline & Geração de ruídos & $\begin{array}{l}\text { ABNT NBR } 10.152 \\
\text { Resoluçấo CONAMA nº 1/ } 1990 \\
\end{array}$ \\
\hline & $\begin{array}{l}\text { Geração de emprego especializado e } \\
\text { renda }\end{array}$ & Não aplicável \\
\hline \multirow{11}{*}{ Exploração } & Geração de lama e cascalho & Lei No $12305 / 2010$ \\
\hline & $\begin{array}{l}\text { Geração de resíduos sólidos e efluentes } \\
\text { líquidos }\end{array}$ & $\begin{array}{l}\text { Lei No } 12305 / 2010 \\
\text { Resoluçáo CONAMA nº 430/ } 2011\end{array}$ \\
\hline & Erosão & Decreto $^{\circ} 76.470 / 1975$ \\
\hline & Desmatamento & Lei ${ }^{\circ} 9.604 / 1998$ \\
\hline & Afugentamento da fauna & Lei n $9.604 / 1998$ \\
\hline & Poluição sonora & $\begin{array}{l}\text { ABNT NBR } 10.152 \\
\text { Resolução CONAMA n 1/ } 1990\end{array}$ \\
\hline & Poluição do ar por emissóes atmosféricas & $\begin{array}{l}\text { Portaria IBAMA n } 348 \text { de 14/03/1990 } \\
\text { PRONAR } \\
\text { Resolução CONAMA no 5/1989 }\end{array}$ \\
\hline & Alteração da estabilidade do ecossistema & Lei n $9.604 / 1998$ \\
\hline & Alteraçáo das propriedades do solo & Resolução CONAMA n 420/ 2009 \\
\hline & Geração de emprego e renda & Não aplicável \\
\hline & Geração de royalties & Não aplicável \\
\hline
\end{tabular}




\begin{tabular}{|c|c|c|}
\hline FASE & $\begin{array}{l}\text { ASPECTOS E IMPACTOS AMBIEN- } \\
\text { TAIS }\end{array}$ & REQUISITOS LEGAIS APLICADOS \\
\hline \multirow{9}{*}{ Perfuração } & $\begin{array}{l}\text { Geração de resíduos sólidos e efluentes } \\
\text { líquidos }\end{array}$ & $\begin{array}{l}\text { Lei No } 12305 \text { / } \\
\text { Resoluçáo CONAMA n 430/ } 2011\end{array}$ \\
\hline & Poluição do ar por emissóes atmosféricas & $\begin{array}{l}\text { Portaria IBAMA n } 348 \text { de 14/03/1990 } \\
\text { PRONAR } \\
\text { Resoluçáo CONAMA no 5/1989 }\end{array}$ \\
\hline & Erosão & Decreto $\mathrm{n}^{\circ} 76.470 / 1975$ \\
\hline & Afugentamento da fauna & Lei $n^{\circ} 9.604 / 1998$ \\
\hline & Alteração da estabilidade do ecossistema & Lei $n^{\circ} 9.604 / 1998$ \\
\hline & Supressão vegetal & Lei n $9.604 / 1998$ \\
\hline & Geração de ruídos & $\begin{array}{l}\text { ABNT NBR } 10.152 \\
\text { Resoluçáo CONAMA nº } 1 / 1990\end{array}$ \\
\hline & Geração de emprego e renda & Não aplicável \\
\hline & Geração de royalties & Não aplicável \\
\hline \multirow{7}{*}{ Complementação } & Geração de ruídos & $\begin{array}{l}\text { ABNT NBR 10.152 } \\
\text { Resoluçẫo CONAMA nº 1/ } 1990\end{array}$ \\
\hline & $\begin{array}{l}\text { Geração de resíduos sólidos e efluentes } \\
\text { líquidos }\end{array}$ & $\begin{array}{l}\text { Lei No } 12305 / \\
\text { Resoluçáo CONAMA nº 430/ } 2011\end{array}$ \\
\hline & Contaminação da água & Lei $n^{\circ} 9.433 / 1997$ \\
\hline & Degradação do solo & Resolução CONAMA n 420/ 2009 \\
\hline & Alteração dos compartimentos ambientais & 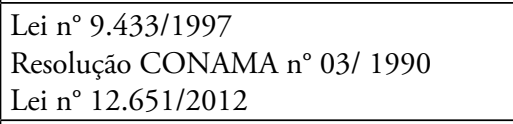 \\
\hline & Geraçáo de emprego e renda & Náo aplicável \\
\hline & Geração de royalties & Não aplicável \\
\hline \multirow{9}{*}{ Elevação } & Poluição sonora e visual & $\begin{array}{l}\text { ABNT NBR } 10.152 \\
\text { Resoluçáo CONAMA nº 1/ } 1990\end{array}$ \\
\hline & $\begin{array}{l}\text { Geração de resíduos sólidos e efluentes } \\
\text { líquidos }\end{array}$ & $\begin{array}{l}\text { Lei No } 12305 \text { /2010 } \\
\text { Resoluçấo CONAMA n 430/ } 2011\end{array}$ \\
\hline & Poluição do ar por emissões atmosféricas & $\begin{array}{l}\text { Portaria IBAMA n } 348 \text { de 14/03/1990 } \\
\text { PRONAR } \\
\text { Resolução CONAMA nº 5/1989 }\end{array}$ \\
\hline & Retirada de material de empréstimo & Lei $n^{\circ} 6.938 / 1981$ \\
\hline & Desmatamento & $\begin{array}{l}\text { Lei } n^{\circ} 9.604 / 1998 \\
\text { Lei } n^{\circ} 12.651 / 2012 \\
\end{array}$ \\
\hline & Afugentamento parcial da fauna & Lei $n^{\circ} 9.604 / 1998$ \\
\hline & $\begin{array}{l}\text { Alteraçóes na dinâmica de uso e ocupação } \\
\text { do solo }\end{array}$ & Decreto $\mathrm{n}^{\circ} 76.470 / 1975$ \\
\hline & Geração de emprego e renda & Não aplicável \\
\hline & Geração de royalties & Não aplicável \\
\hline
\end{tabular}




\begin{tabular}{|c|c|c|}
\hline FASE & $\begin{array}{c}\text { ASPECTOS E IMPACTOS AMBIEN- } \\
\text { TAIS }\end{array}$ & REQUISITOS LEGAIS APLICADOS \\
\hline \multirow{9}{*}{ Produção } & Riscos à saúde dos trabalhadores & $\begin{array}{l}\text { Norma Ministério do Trabalho NR-4 } \\
/ 1978 \\
\text { Portaria SST n } 25 \text { de 29/12/1994 }\end{array}$ \\
\hline & $\begin{array}{l}\text { Geraçáo de resíduos sólidos e efluentes } \\
\text { líquidos }\end{array}$ & $\begin{array}{l}\text { Lei No } 12305 \text { / } 2010 \\
\text { Resolução CONAMA n 430/ } 2011\end{array}$ \\
\hline & Derramamento de óleo & Resolução CONAMA n 398/ 2008 \\
\hline & Interferência na fauna local e flora local & Lei $n^{\circ} 9.604 / 1998$ \\
\hline & Poluição do ar por emissões atmosféricas & $\begin{array}{l}\text { Portaria IBAMA nº } 348 \text { de 14/03/1990 } \\
\text { PRONAR } \\
\text { Resolução CONAMA no 5/1989 }\end{array}$ \\
\hline & Geração de emprego e renda & Não aplicável \\
\hline & Geração de royalties & Não aplicável \\
\hline & Geração de energia e combustível & Lei Federal no 9.478/1997 \\
\hline & Projeção da região no cenário nacional & Não aplicável \\
\hline
\end{tabular}

Cabe ressaltar, as atividades, processos e produtos desenvolvidos no CPCA/RN são orientadas de forma geral pelos regulamentos: Lei Federal $\mathrm{N}^{\circ}$ 6.938/1981; Decreto $\mathrm{N}^{\circ}$ 99.274/1990; Resolução CONAMA N²37/1997 e; Resolução CONAMA Nº 01/1986.

\subsubsection{Açóes de gestáo ambiental na área de estudo}

As ações de gestão ambiental no CPCA/RN são praticamente desenvolvidas por empresas que atuam na área, onde em sua maioria das vezes não tem interrelação com as instituiçóes e, são caracterizadas como pontuais, sem periodicidade, imediatista e, concentradas em determinados setores.

Observou-se ações no âmbito ambiental voltadas para Plano de Gerenciamento de Resíduos Sólidos - PGRS, através parceria entre Petrobras e IDEMA, com a finalidade de tratamento, aproveitamento e a disposição dos resíduos estocados na área investigada. Em parcerias com as Instituições de Ensino Superior - IES (UFRN, UFERSA, e UERN) a Petrobras atualmente vem sendo desenvolvido um Projeto de Recuperação de Áreas Degradadas, com finalidade de reabilitar áreas de materiais de empréstimos. Ressalta ainda ações de educação ambiental com a população, porém de forma pontual (PETROBRAS, 2015).

Constatou-se que no tocante as ações sociais desenvolvidas nos municípios que o CPCA/RN encontra-se localizado destacam-se: O Esporte é Minha Praia (Areia Branca) e Ousadia Juvenil (Mossoró) (PETROBRAS, 2015). Entretanto, percebe-se que ambos os projetos são desenvolvidos com populações que não estão inseridas nas comunidades rurais pertencentes ao campo petrolífero investigado.

Evidenciou-se também ações com fins socioeconômicos, como por exemplo projetos de economia solidária em parceria com ONGs que atuam na região (PETROBRAS, 2015). 
No entanto, ainda encontra-se centralizada em algumas comunidades rurais e, sem ter alcance universal na população local.

Portanto, percebe-se que ações que visam atenuar a problemática socioeconômica e ambiental da área investigada ocorrem de forma tímida e, tornam-se fragilizadas devido a falta de sintonia entre os órgãos de fomentos e os executores.

\subsection{Planejamento e gerenciamento ambiental do CPCA/RN}

A proposta de planejamento e gerenciamento ambiental da área do CPCA/RN consiste na determinação dos planos, programas e projetos para a manutenção, aprevenção, a correção e o controle das atividades, processos e produtos desenvolvidos na referida região, sendo organizados conformes à intervenção nos aspectos ambientais, sociais e econômicos.

Cabe ressaltar, que dentro desse planejamento não irá abordar aspectos relacionados com acidentes que afetam o meio físico, biótico ou socioeconômico. Entrentanto, entendese que são importantes dentro da avaliação ambiental da cadeia energética do petróleo.

Com isso, a proposição de açóes para variável ambiental envolve os compartimentos: água, solo, biota e, ar (TABELA 02). As pressuposiçóes de iniciativas sociais relacionamse com os colaboradores, a vizinhança e a sociedade (TABELA 03). As suposiçóes dos projetos econômicos e multidisciplinares estimularam-se na formulação de novos circuitos econômicos, aprimoramento de tecnologias de exploração de petróleo e gás e, criação de tecnologias ambientais (Tabelas 04).

Tabela 02 - Matriz de Planejamento Ambiental para o CPCA/RN com abordagem ambiental

\begin{tabular}{|c|c|c|c|c|c|c|c|c|c|}
\hline \multirow[b]{2}{*}{ ASPECTO } & \multicolumn{5}{|c|}{ PLANEJAMENTO AMBIENTAL } & \multicolumn{4}{|c|}{ GERENCIAMENTO AMBIENTAL } \\
\hline & OBJETIVO & AÇÃO & RESPONSÁVEL & META & PRAZO & ETAPAS & MONITORAMENTO & INDICADOR & ANÁLISE \\
\hline $\begin{array}{lr}\text { Usos } & \text { dos } \\
\text { Recursos } & \text { Hí- } \\
\text { dricos. } & \\
\end{array}$ & $\begin{array}{l}\text { Identificar os sistemas } \\
\text { hídricos, apontar seus } \\
\text { usos, determinar as } \\
\text { fontes de poluiçáo e } \\
\text { seus efeitos. }\end{array}$ & 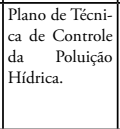 & $\begin{array}{|lr|}\text { Exploradora } & \text { de } \\
\text { Petróleo, } & \text { Univer- } \\
\text { sidades, Prefeitu- } \\
\text { ras e,Órgáos re de } \\
\text { Recursos } & \text { Hídricos } \\
\text { Estaduais. }\end{array}$ & \begin{tabular}{|llll} 
Regular \\
1 & 0 & 0 & $\%$ \\
desses & sis- \\
temas & em \\
5 anos.
\end{tabular} & 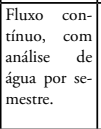 & $\begin{array}{l}\text { Identificaçáo e levantamento } \\
\text { os sistemas hídricos; caracte- } \\
\text { rizaçáo dos sistemas hídricos; } \\
\text { determinaçáo dos métodos } \\
\text { analíticos e; tratamento de } \\
\text { dados. }\end{array}$ & $\begin{array}{l}\text { Monitoramento com os parâ- } \\
\text { metros físicos, químicos e bio- } \\
\text { lógicos dos recursos hídricos. } \\
\text { Além disso, torna-se crucial } \\
\text { uma investigaçáo quantitativa } \\
\text { da água. }\end{array}$ & \begin{tabular}{|l|} 
Qu a lid a d e \\
físico-química \\
e biológica da \\
água.
\end{tabular} & $\begin{array}{l}\text { Órgáos de } \\
\text { Recursos } \\
\text { H íd r i cos } \\
\text { Estaduais. }\end{array}$ \\
\hline $\begin{array}{l}\text { Degradaçáo } \\
\text { do Solo. }\end{array}$ & $\begin{array}{l}\text { Realizar um levanta- } \\
\text { mento do meio físico, } \\
\text { interpretar riscos e ca- } \\
\text { pacidades de uso para } \\
\text { reduçáo da degradaçáo } \\
\text { das terras e, elaborar } \\
\text { um plano de açóes } \\
\text { para uso sustentável } \\
\text { do recurso solo. }\end{array}$ & $\begin{array}{l}\begin{array}{l}\text { Plano de Ma- } \\
\text { nejo e Conser- } \\
\text { vaçáo do solo }\end{array} \\
\end{array}$ & 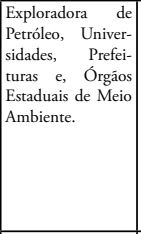 & 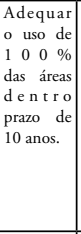 & $\begin{array}{|lr|}\text { Fluxo } & \text { con- } \\
\text { tínuo, } & \text { com } \\
\text { análise } & \text { de } \\
\text { solo a cada } 5 \\
\text { anos. }\end{array}$ & \begin{tabular}{|l|} 
Classificaçáo dos tipos de \\
solos; classificaçáo dos usos \\
da terra; definiçâao da aptidaao \\
dos usos da terra; identifica- \\
çáo de locais de degradaçáo \\
ambiental; elaboraçáo das \\
açóes de manejo do solo; \\
proposiçáo de medidas de \\
conservaçáo do solo e; moni- \\
toramento do plano de ma- \\
nejo e conservaçáo do solo.
\end{tabular} & $\begin{array}{l}\text { Para efetivaçáo das açóes faz se } \\
\text { necessário à execuçâo de audi- } \\
\text { torias ambientais para checar } \\
\text { as conformidades e náo con- } \\
\text { formidades ao longo da imple- } \\
\text { mentaçáo do plano e, propor } \\
\text { as respectivas açóes corretivas, } \\
\text { bem como a realizaçáo de testes } \\
\text { de verificaçáo das características } \\
\text { fisicas, químicas e biológicas. }\end{array}$ & \begin{tabular}{|l} 
Qu a li d a d e \\
físico-química \\
e biológica do \\
solo.
\end{tabular} & $\begin{array}{l}\text { Ó r g á o s } \\
\text { Estadua is } \\
\text { der Meio } \\
\text { Ambiente. }\end{array}$ \\
\hline $\begin{array}{l}\text { Alteraçáo } \\
\text { dos com- } \\
\text { partimentos } \\
\text { ambientais }\end{array}$ & $\begin{array}{l}\text { Visa reabilitar, re- } \\
\text { cuperar e, restaurar } \\
\text { áreas degradadas pela } \\
\text { atividade petrolífera, } \\
\text { conforme as condiçóes } \\
\text { naturais anteriores e/ } \\
\text { ou semelhantes. }\end{array}$ & $\begin{array}{|lrr|}\text { Plano } & \text { de } & \text { Re- } \\
\text { cuperaçáo } & \text { de } \\
\text { Áreas } & \text { Degra- } \\
\text { dadas } & & \\
& & \\
& & \\
\end{array}$ & 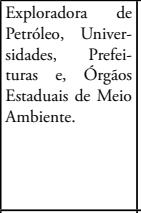 & 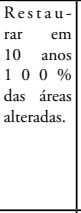 & 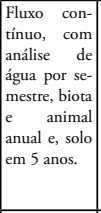 & \begin{tabular}{|l|} 
Diagnóstico ambiental, \\
Planejamento ambiental e, \\
gestáo ambiental. Com are- \\
composiçáo das áreas afetada \\
pela atividade petrolífera, tais \\
como os canteiros de obra, \\
jazidas, matas ciliares e, áreas \\
de extraçáa de areia.
\end{tabular} & $\begin{array}{l}\text { Monitoramento do mapea- } \\
\text { mento das áreas degradadas } \\
\text { em superfície obtidas a partir } \\
\text { da interpretaçáo de fotogra- } \\
\text { fias aéreas; indicadores de } \\
\text { qualidade da sucessáo vegetal; } \\
\text { indicadores de qualidade dos } \\
\text { recursos hídricos superficiais e } \\
\text { subterrâneos e; indicadores de } \\
\text { qualidade do solo. }\end{array}$ & \begin{tabular}{|l|} 
Q u a l i d a d e \\
físico-química \\
e biológica da \\
água, compo- \\
siçáo da biota, \\
densidade ani- \\
mal e, fertilida- \\
de do Solo.
\end{tabular} & $\begin{array}{l}\text { Ó r g á o s } \\
\text { E stad ua is } \\
\text { de Meio } \\
\text { Ambiente. } \\
\\
\\
\end{array}$ \\
\hline $\begin{array}{l}\text { Process os } \\
\text { Erosivos. }\end{array}$ & $\begin{array}{l}\text { Avaliar o estágio da } \\
\text { degradaçáo ambiental, } \\
\text { bem como propor me- } \\
\text { didas atenuantes para } \\
\text { situaçáo problema. }\end{array}$ & $\begin{array}{l}\text { Plano de Técni- } \\
\text { cas de Preven- } \\
\text { çáo e Controle } \\
\text { da Erosáo }\end{array}$ & 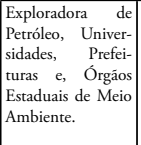 & \begin{tabular}{|l|} 
Controlar \\
$100 \%$ dos \\
casos de \\
áreas ero- \\
didas em \\
5 anos. \\
\end{tabular} & 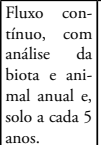 & $\begin{array}{l}\text { Caracterizar a situaçáo dos } \\
\text { solos erodidos; executar } \\
\text { açóes para prevençáo e con- } \\
\text { trole a erosão de solos e; } \\
\text { monitoramento das açóes } \\
\text { executadas. }\end{array}$ & $\begin{array}{l}\text { Monitoramento da prevençáo } \\
\text { e controle da erosáo, por meio } \\
\text { de testes da umidade do solo, } \\
\text { determinaçáo do escoamento } \\
\text { superficial e uso de imagens } \\
\text { da cobertura foliar para com- } \\
\text { paracáo. }\end{array}$ & $\begin{array}{l}\text { Composiçáa } \\
\text { da biota, den- } \\
\text { sidade animal } \\
\text { e, fertilidade do } \\
\text { solo e, quanti- } \\
\text { ficaçáa de sedi- } \\
\text { mentos. }\end{array}$ & 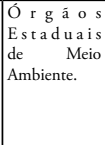 \\
\hline
\end{tabular}




\begin{tabular}{|c|c|c|c|c|c|c|c|c|c|}
\hline \multirow[b]{2}{*}{ ASPECTO } & \multicolumn{5}{|c|}{ PLANEJAMENTO AMBIENTAL } & \multicolumn{4}{|c|}{ GERENCIAMENTO AMBIENTAL } \\
\hline & OBJETIVO & AÇÁ̉O & RESPONSÁVEL & META & PRAZO & ETAPAS & MONITORAMENTO & INDICADOR & ANÁLISE \\
\hline $\begin{array}{l}\text { Desma- } \\
\text { tamento, } \\
\text { supressáo } \\
\text { vegetal, in- } \\
\text { terferência } \\
\text { na fauna e } \\
\text { flora. }\end{array}$ & $\begin{array}{l}\text { Mapear aéreas sus- } \\
\text { ceptiveis a degradaçáo } \\
\text { ambiental,bem como } \\
\text { elaborar uma propos- } \\
\text { ta de reflorestamento } \\
\text { de áreas degradadas } \\
\text { investigadas. }\end{array}$ & \begin{tabular}{|l|} 
Plano de Reflo- \\
restamento
\end{tabular} & $\begin{array}{l}\text { Exploradora de } \\
\text { Petróleo, Universi- } \\
\text { dades, Prefeituras, } \\
\text { ONGs e, Órgãos } \\
\text { Estaduais de Meio } \\
\text { Ambiente. }\end{array}$ & $\begin{array}{|lr|}\text { Executar } \\
0 & \text { projeto } \\
\text { em } & 100 \% \\
\text { da } & \text { área } \\
\text { alt terada } \\
\text { dentro de } \\
\text { um } & \text { prazo } \\
\text { de } & 10 \\
\text { anos. }\end{array}$ & $\begin{array}{|lr|}\text { Fluxo r con- } \\
\text { tínuo, } & \text { com } \\
\text { análise } & \text { da } \\
\text { biota } & \text { e ani- } \\
\text { mal anual e, } \\
\text { solo a cada } 5 \\
\text { anos. }\end{array}$ & $\begin{array}{l}\text { Informaçóes do projeto; } \\
\text { definiçáo dos parceiros; de- } \\
\text { limitaçáo dos objetivos e es- } \\
\text { copo do plano; elaboraçâo da } \\
\text { justificativa; informativo da } \\
\text { área; descriçâo do ambien- } \\
\text { te; zoneamento do uso da } \\
\text { terra; descriçáo dos recursos } \\
\text { florestais; fundamentaçáo } \\
\text { do reflorestamento; definiçáo } \\
\text { dos investimentos, métodos } \\
\text { e responsabilidades e; execu- } \\
\text { çáo das açóes. } \\
\end{array}$ & $\begin{array}{l}\text { O monitoramento através do } \\
\text { uso de geoprocessamento, ae- } \\
\text { rofotometria e do acompanha- } \\
\text { mento da comunidade vegetal, } \\
\text { com os parâmetros estruturais } \\
\text { de riqueza, altura, diâmetro, } \\
\text { densidade, diversidade, fre- } \\
\text { quência e área basal. } \\
\end{array}$ & $\begin{array}{l}\text { Composiçáo } \\
\text { da biota, den- } \\
\text { sidade animal } \\
\text { e, qualidade } \\
\text { físico-química } \\
\text { e biológica do } \\
\text { solo. }\end{array}$ & $\begin{array}{l}\text { Ó r g áa or } \\
\text { Estadua is } \\
\text { de Meio } \\
\text { Ambiente. }\end{array}$ \\
\hline $\begin{array}{l}\text { Afugenta- } \\
\text { mento } \quad \mathrm{da} \\
\text { fauna }\end{array}$ & $\begin{array}{l}\text { Criar habitats para de- } \\
\text { senvolver a reintrodu- } \\
\text { çáo de espécies local. }\end{array}$ & $\begin{array}{l}\text { Plano de Ma- } \\
\text { nejo Animal }\end{array}$ & 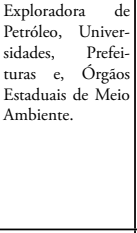 & 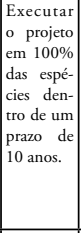 & $\begin{array}{l}\text { Fluxo con- } \\
\text { tínuo, com } \\
\text { análise } \quad \mathrm{da} \\
\text { biota e ani- } \\
\text { mal anual. } \\
\end{array}$ & $\begin{array}{l}\text { Levantamento das espécies; } \\
\text { identificaçáo das áreas de } \\
\text { com sensibilidade; descriçáo } \\
\text { das açóes de resgate e realo- } \\
\text { caçáo das espécies; definiçáo } \\
\text { das áreas de captura e soltu- } \\
\text { ra; determinaçâo das espécies } \\
\text { indicadores; realizaçâo de de } \\
\text { estudos de conservaçáo e; } \\
\text { estabelecimento de medidas } \\
\text { de recuperaçáo. } \\
\end{array}$ & $\begin{array}{l}\text { Monitoramento com os parâ- } \\
\text { metros estruturais de quan- } \\
\text { tidade de espécie, densidade, } \\
\text { diversidade, frequência e, dis- } \\
\text { tribuiçáo. }\end{array}$ & $\begin{array}{l}\text { Composiçáo da } \\
\text { biota e, densi- } \\
\text { dade animal. }\end{array}$ & $\begin{array}{l}\text { Ó r g gá or } \\
\text { Estaduais } \\
\text { Municipais } \\
\text { der Meio } \\
\text { Ambiente. }\end{array}$ \\
\hline $\begin{array}{ll}\text { Geraçáo } & \text { de } \\
\text { ruídos } & \end{array}$ & $\begin{array}{l}\text { Identificar os prin- } \\
\text { cipais aspectos am- } \\
\text { bientais da geraçáo de } \\
\text { ruídos e, propor açóes } \\
\text { atenuantes para pro- } \\
\text { blemática. }\end{array}$ & $\begin{array}{l}\text { Plano de Medi- } \\
\text { das de Controle } \\
\text { de Ruídos }\end{array}$ & $\begin{array}{l}\text { Exploradora de } \\
\text { Petróleo, Presta- } \\
\text { dora de Serviços e, } \\
\text { Universidades. }\end{array}$ & 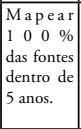 & $\begin{array}{|lr|}\text { Fluxo r } & \text { con- } \\
\text { tínuo, } & \text { com } \\
\text { análise } & \text { de } \\
\text { ruídos anual. }\end{array}$ & $\begin{array}{l}\text { Identificar, caracterizar, } \\
\text { quantificar, classificar e } \\
\text { medir os pontos de ruídos } \\
\text { na área. }\end{array}$ & $\begin{array}{l}\text { Monitoramento com a me- } \\
\text { diçáo periódica dos níveis de } \\
\text { ruídos e vibraçóes nas áreas de } \\
\text { produçấo, buscando comparar } \\
\text { com os padróes legais estabe- } \\
\text { lecidos. }\end{array}$ & 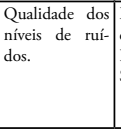 & $\begin{array}{l}\text { Exploradora } \\
\text { de Petróleo e, } \\
\text { Prestadora de } \\
\text { Serviços. }\end{array}$ \\
\hline
\end{tabular}

\section{Tabela 03 - Matriz de Planejamento Ambiental para o CPCA/RN com abordagem social}

\begin{tabular}{|c|c|c|c|c|c|c|c|c|c|}
\hline \multirow[b]{2}{*}{ ASPECTO } & \multicolumn{5}{|c|}{ PLANEJAMENTO AMBIENTAL } & \multicolumn{4}{|c|}{ GERENCIAMENTO AMBIENTAL } \\
\hline & OBJETIVO & AÇÁO & RESPONSÁVEL & META & PRAZO & ETAPAS & MONITORAMENTO & INDICADOR & ANÁLISE \\
\hline $\begin{array}{lr}\text { Geraçáo } & \text { de } \\
\text { emprego } & \mathrm{e} \\
\text { renda } & \\
\end{array}$ & $\begin{array}{l}\text { Capacitar, treinar, } \\
\text { qualificar e sensibili- } \\
\text { zar os colaboradores } \\
\text { visando melhorar seu } \\
\text { desempenho nas suas } \\
\text { atividades executadas. }\end{array}$ & $\begin{array}{l}\text { Programa de } \\
\text { capacitaçáo,- } \\
\text { treinamentos e, } \\
\text { formaçáo. }\end{array}$ & 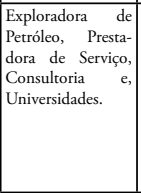 & 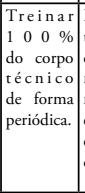 & $\begin{array}{|lr|}\text { Fluxo } & \text { con- } \\
\text { tínuo, } & \text { com } \\
\text { ofertas } & \text { diá- } \\
\text { rias, } & \text { sema- } \\
\text { nais, } & \text { mensais } \\
\text { e } & \text { anuais, } \\
\text { dependendo } \\
\text { da açáo. }\end{array}$ & $\begin{array}{l}\text { Mapeamento das fragilidades } \\
\text { dos colaboradores; execuçâoo } \\
\text { das açóes: palestras, confe- } \\
\text { rências, seminários, cursos, } \\
\text { projetos, visitas técnicas } \\
\text { e simulaçáo nas áreas de } \\
\text { qualidade, segurança, meio } \\
\text { ambiente e saúde e; avaliaçáo } \\
\text { das açóes. }\end{array}$ & \begin{tabular}{|l|} 
Colaboradores envolvidos nas \\
açoses; as açóes diárias, sema- \\
nais, mensais e anuais; quanti- \\
ficar a reduçáo de acidentes e \\
riscos prevenidos e; determinar \\
princípios, objetivos e metas \\
para curto, médio e longo \\
prazo para novas açóes a serem \\
desenvolvidas.
\end{tabular} & \begin{tabular}{|l|}
$\begin{array}{l}\text { Registro } \\
\text { açóes desenvol- } \\
\text { vidas }\end{array}$ \\
\\
\end{tabular} & $\begin{array}{l}\text { Exploradora } \\
\text { de Petróleo, } \\
\text { Prestadora de } \\
\text { Serviços e, } \\
\text { Consultorias. }\end{array}$ \\
\hline $\begin{array}{l}\text { Riscos a saú- } \\
\text { de dos traba- } \\
\text { lhadores. }\end{array}$ & $\begin{array}{l}\text { Objetiva à preservaçáo } \\
\text { da saúde dos colabora- } \\
\text { dores e da populaçáo } \\
\text { situada na área in- } \\
\text { vestigada, através do } \\
\text { controle da ocorrência } \\
\text { de riscos ambientais } \\
\text { potenciais ou existen- } \\
\text { tespor agentes físicos, } \\
\text { químicos e biológicos. }\end{array}$ & $\begin{array}{|lr|}\text { Programa } & \text { de } \\
\text { prevençáo } & \text { de } \\
\text { riscos } & \text { ambien- } \\
\text { tais. } & \\
& \\
& \\
& \\
& \\
& \\
\end{array}$ & $\begin{array}{|lr|}\text { Exploradora } & \text { de } \\
\text { Petróleo, } & \text { Presta- } \\
\text { dora de } & \text { Serviço, } \\
\text { Consultoria } & \text { e, } \\
\text { Universidades. }\end{array}$ & 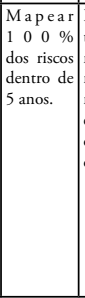 & $\begin{array}{l}\text { Fluxo con- } \\
\text { tínuo, com } \\
\text { medidas diá- } \\
\text { rias, sema- } \\
\text { nais, mensais } \\
\text { e anuais, } \\
\text { dependendo } \\
\text { da açáo. }\end{array}$ & $\begin{array}{l}\text { Reconhecimento dos riscos; } \\
\text { estabelecimento de priori- } \\
\text { dades e metas de avaliaçáo e } \\
\text { controle;avaliaçáo dos riscos } \\
\text { e da exposiçáo dos trabalha- } \\
\text { dores; implantaçáo de medi- } \\
\text { das de controle avaliaçáo de } \\
\text { sua eficácia; monitoramento } \\
\text { da exposiçáa aos riscos e; } \\
\text { registro e divulgaçáo dos } \\
\text { dados. }\end{array}$ & \begin{tabular}{|l|} 
Riscos ambientais, incluindo \\
informaçóes sobre o tráfego, o \\
controle de armazenamento de \\
produtos perigosos, o controle \\
nas atividades de abastecimen- \\
to de veículos e máquinas, \\
sensibilizaçáo ambiental e trei- \\
namento, a divulgaçáo das in- \\
formaçóes sobre as substâncias \\
químicas, o controle da saúde \\
dos trabalhadores, a investiga- \\
çáo de acidentes, as inspeçóes \\
de segurança e o controle de \\
registros.
\end{tabular} & \begin{tabular}{|l|} 
Registro de \\
açóes preventi- \\
vas concluídas. \\
Número de re- \\
clamaçóes/ano \\
\\
\\
\\
\end{tabular} & $\begin{array}{l}\text { Exploradora } \\
\text { de Petróleo, } \\
\text { Prestadora de } \\
\text { Serviços e, } \\
\text { Consultorias. }\end{array}$ \\
\hline $\begin{array}{lr}\text { Geraçáo } & \text { de } \\
\text { emprego } & \mathrm{e} \\
\text { renda } & \end{array}$ & $\begin{array}{l}\text { Esclarecer as popula- } \\
\text { çôs locais sobre aspec- } \\
\text { tos gerais da atividade } \\
\text { petrolífera; qualidade } \\
\text { de vida; saneamento } \\
\text { ambiental e economia } \\
\text { solidária. }\end{array}$ & 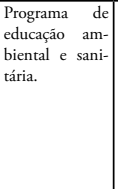 & \begin{tabular}{|l|} 
Exploradora de \\
Petróleo, Presta- \\
dora de Serviços e, \\
Universidades. \\
\end{tabular} & 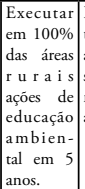 & $\begin{array}{l}\text { Fluxo con- } \\
\text { tínuo, com } \\
\text { açóes diárias, } \\
\text { se ma a a is, } \\
\text { mensais e } \\
\text { anuais. }\end{array}$ & $\begin{array}{l}\text { Planejamento das açóes; } \\
\text { execuçâa das açôes: oficinas, } \\
\text { conferências, seminários, } \\
\text { cursos, projetos, visitas } \\
\text { técnicas, aulas de campo, } \\
\text { comunicação e divulgaçâa e; } \\
\text { avaliaçáa das açóes. }\end{array}$ & $\begin{array}{l}\text { Quantitativo de açós sobre As- } \\
\text { pectos Impactos Ambientais da } \\
\text { Atividade Petrolífera; Qualida- } \\
\text { de, Segurança, Meio Ambiente } \\
\text { e Saúde;Saneamento Ambien- } \\
\text { tal; Economia Solidária; Agroe- } \\
\text { cologia; Empreendedorismo e; } \\
\text { Noçóes de Contabilidade. }\end{array}$ & \begin{tabular}{|l|} 
Registro de \\
projetos desen- \\
volvidos.
\end{tabular} & $\begin{array}{l}\text { Exploradora } \\
\text { de Petróleo, } \\
\text { Prestadora de } \\
\text { Serviços e, } \\
\text { Consultorias. }\end{array}$ \\
\hline
\end{tabular}




\section{Tabela 04 - Matriz de Planejamento Ambiental para o CPCA/RN com abordagem interdisciplinar}

\begin{tabular}{|c|c|c|c|c|c|c|c|c|c|}
\hline \multirow[b]{2}{*}{ ASPECTO } & \multicolumn{5}{|c|}{ PLANEJAMENTO AMBIENTAL } & \multicolumn{4}{|c|}{ GERENCIAMENTO AMBIENTAL } \\
\hline & OBJETIVO & AÇÁO & RESPONSÁVEL & META & PRAZO & ETAPAS & MONITORAMENTO & INDICADOR & ANÁLISE \\
\hline $\begin{array}{ll}\text { Geraçáo } & \text { de } \\
\text { efluentes } & \text { lí- } \\
\text { quidos. } & \end{array}$ & $\begin{array}{l}\text { Tem por finalidade } \\
\text { assegurar a preservaçáo } \\
\text { ambiental através de } \\
\text { medidas de controle } \\
\text { da poluiçáo de efluen- } \\
\text { tes líquidos gerados no } \\
\text { CPCA/RN. }\end{array}$ & $\begin{array}{l}\text { Projeto de ges- } \\
\text { táo de efluentes } \\
\text { líquidos. }\end{array}$ & \begin{tabular}{|l|} 
Exploradorar de \\
Petróleo, Presta- \\
dora de Serviço, e, \\
Universidades. \\
\end{tabular} & 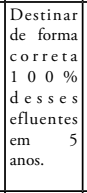 & 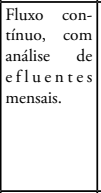 & $\begin{array}{l}\text { Caracterizaçáo das vias de } \\
\text { efluentes; classificaçáo, se- } \\
\text { paraçáo, coleta e transporta } \\
\text { dos efluentes conforme suas } \\
\text { características físicas, quími- } \\
\text { cas e biológicas; realizaçáo } \\
\text { do tratamento dos efluentes } \\
\text { e; destinaçáo adequada dos } \\
\text { efluentes nâo tratados. }\end{array}$ & $\begin{array}{l}\text { Monitoramento qualitativo e } \\
\text { quantitativodos efluentes líqui- } \\
\text { dos nas fases de identificaçáo, } \\
\text { caracterizaçấo, quantificaçâo, } \\
\text { classificaçáo, manuseio, acon- } \\
\text { dicionamento, armazenamento } \\
\text { temporário, tratamento e dis- } \\
\text { posiçáo final. }\end{array}$ & $\begin{array}{l}\text { Qualidade dos } \\
\text { efluentes líqui- } \\
\text { dos, no âmbito } \\
\text { dos aspectos } \\
\text { físico-químico } \\
\text { e biológicos. }\end{array}$ & 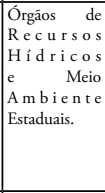 \\
\hline $\begin{array}{ll}\text { Geraçáo de } \\
\text { óleo. }\end{array}$ & $\begin{array}{l}\text { Objetiva buscar a pre- } \\
\text { vençáo ambiental das } \\
\text { atividades, processos e } \\
\text { produtos relacionados } \\
\text { com a geraçáo de óleos } \\
\text { no CPCA/RN, através } \\
\text { da identificaçáo das } \\
\text { áreas com potencial de } \\
\text { ocorrência de riscos de } \\
\text { acidentes de derrama- } \\
\text { mento de óleo. } \\
\end{array}$ & \begin{tabular}{|l|}
$\begin{array}{l}\text { Projeto de con- } \\
\text { tingenciamento } \\
\text { de óleo. }\end{array}$ \\
\\
\\
\end{tabular} & $\begin{array}{|lr|}\text { Exploradora } & \text { de } \\
\text { Petróleo, } & \text { Presta- } \\
\text { dora de } & \text { Serviço, } \\
\text { Consultoria } & \text { e, } \\
\text { Universidades. } & \end{array}$ & 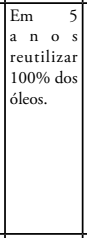 & $\begin{array}{|lr|}\text { Fluxo r con- } \\
\text { tínuo, com } \\
\text { mediçấo do } \\
\text { teor de } & \text { óleo } \\
\text { mensal } & \text { e } \\
\text { inspeçáo das } \\
\text { áreas. }\end{array}$ & $\begin{array}{l}\text { Identificaçáo; caracterizaçáo; } \\
\text { quantificaçáo; classificaçáo e } \\
\text { mediçáo da geraçáo de óleo } \\
\text { na regiáo investigada e das } \\
\text { áreas com potencial de der- } \\
\text { ramamento de óleo. }\end{array}$ & $\begin{array}{l}\text { Quantificaçáo das áreas sus- } \\
\text { ceptíveis para derramamento } \\
\text { de óleo; da coleta; do trans- } \\
\text { porte;do armazenamento; do } \\
\text { tratamento e; do destino final } \\
\text { desse produto. }\end{array}$ & 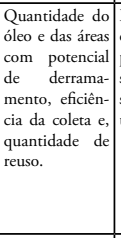 & $\begin{array}{l}\text { Exploradora } \\
\text { de petróleo, } \\
\text { prestadora de } \\
\text { serviços, con- } \\
\text { sultorias e, } \\
\text { universidades. }\end{array}$ \\
\hline $\begin{array}{ll}\text { Geraçáo } & \text { de } \\
\text { efluentes } & \text { in- } \\
\text { dustriais. }\end{array}$ & $\begin{array}{l}\text { Tratar os efluentes } \\
\text { industriais através do } \\
\text { reuso no processo pro- } \\
\text { dutivo e, realizar sua } \\
\text { destinaçáa de forma } \\
\text { adequada atendendo } \\
\text { os aspectos legais. }\end{array}$ & \begin{tabular}{|l|} 
Projeto de reu- \\
so de efluentes \\
industriais
\end{tabular} & 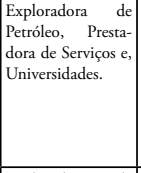 & 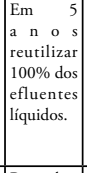 & $\begin{array}{|lr|}\text { Fluxo } & \text { con- } \\
\text { tínuo, } & \text { com } \\
\text { açóes } & \text { men- } \\
\text { sais. } & \\
& \\
& \\
\end{array}$ & $\begin{array}{l}\text { Diagnóstico das fontes gera- } \\
\text { doras; elaboraçáa de estudo } \\
\text { de tratamento; premissas } \\
\text { para elaboraçáo do projeto; } \\
\text { avaliaçáo da viabilidade } \\
\text { econômica do projeto e; } \\
\text { implementaçáo do reuso de } \\
\text { efluente industrial. } \\
\end{array}$ & $\begin{array}{l}\text { Monitoramento do reuso } \\
\text { de efluentes industriais será } \\
\text { por meio da identificaçáo, } \\
\text { caracterizaçâo, quantificaçao, } \\
\text { classificaçáo, reuso primário; } \\
\text { reuso secundário; tratamento e } \\
\text { disposiçáo final. }\end{array}$ & \begin{tabular}{|lr} 
Qualidade & do \\
efluente; & efi- \\
ciência do reuso \\
e; & quantidade \\
do efluente. &
\end{tabular} & $\begin{array}{l}\text { Exploradora } \\
\text { de petróleo, } \\
\text { prestadora de } \\
\text { serviços, con- } \\
\text { sultorias e, } \\
\text { universidades. }\end{array}$ \\
\hline $\begin{array}{ll}\text { Geraçáo } & \text { de } \\
\text { emissôes } & \text { at- } \\
\text { mosféricas }\end{array}$ & $\begin{array}{l}\text { Identificar as princi- } \\
\text { pais fontes de emissóes } \\
\text { atmosféricas, os prin- } \\
\text { cipais gases emitidos e } \\
\text { elaborar uma proposta } \\
\text { para problemática. }\end{array}$ & \begin{tabular}{|l|} 
Projeto de ges- \\
táo de emissóes \\
atmosféricas. \\
\end{tabular} & \begin{tabular}{|l|} 
Exploradora re de \\
Petróleo, Presta- \\
dora de Serviço, e, \\
Universidades.
\end{tabular} & $\begin{array}{l}\text { Regular } \\
100 \% \text { das } \\
\text { fontes em } \\
5 \text { anos. }\end{array}$ & $\begin{array}{|lr|}\text { Fluxo } & \text { con- } \\
\text { tínuo, } & \text { com } \\
\text { análise } & \text { das } \\
\text { e m is s ô es } \\
\text { mensais. }\end{array}$ & \begin{tabular}{|l|} 
Identificaçáo, caracterizaçấo, \\
quantificaçáo, classificaçáo, \\
mediçáoe controle das emis- \\
sóes dos gases do efeito estufa \\
da área investigada. \\
\\
\end{tabular} & $\begin{array}{l}\text { Monitoramentodesse processo } \\
\text { ocorre através de registro dos } \\
\text { tipos de gases emitidos; quanti- } \\
\text { dade emitida; período de maior } \\
\text { emissão; atividades, processos } \\
\text { e/ou produtos emissores; área } \\
\text { de influência da emissão e; } \\
\text { técnicas adotadas para controle } \\
\text { da emissão. }\end{array}$ & 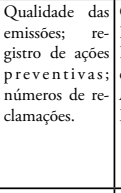 & 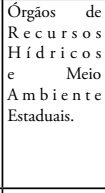 \\
\hline $\begin{array}{lr}\text { Geraçáo } & \text { de } \\
\text { emissóes vei- } \\
\text { culares. }\end{array}$ & $\begin{array}{l}\text { Investigar a qualidade } \\
\text { das emissóes veiculares } \\
\text { no CPCA/RN. }\end{array}$ & \begin{tabular}{|l|} 
Projeto inspe- \\
çáo veicular.
\end{tabular} & 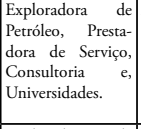 & $\begin{array}{l}\text { Adequar } \\
100 \% \text { das } \\
\text { frotas em } \\
2 \text { anos. }\end{array}$ & $\begin{array}{l}\text { Fluxo con- } \\
\text { tínuo, com } \\
\text { mediçáo das } \\
\text { e m is s só es } \\
\text { mensais. }\end{array}$ & 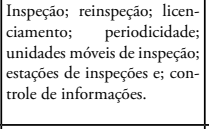 & $\begin{array}{l}\text { Quantidade de fiscalizaçáo } \\
\text { da frota; monitoramento da } \\
\text { qualidade do ar, quantidade de } \\
\text { acidentes e criaçáo de relatórios } \\
\text { de monitoramento relacionado } \\
\text { à frota. }\end{array}$ & 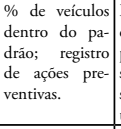 & $\begin{array}{l}\text { Exploradora } \\
\text { de petróleo, } \\
\text { prestadora de } \\
\text { serviços, con- } \\
\text { sultorias e, } \\
\text { universidades. }\end{array}$ \\
\hline $\begin{array}{lr}\text { Geraçáo } & \text { de } \\
\text { poluiçáo } & \text { so- } \\
\text { nora. } & \end{array}$ & $\begin{array}{l}\text { Objetiva investigar a } \\
\text { qualidade da sonora } \\
\text { das atividades, proces- } \\
\text { sos e produtos desen- } \\
\text { volvidos no CPCA/ } \\
\text { RN. }\end{array}$ & \begin{tabular}{|l|} 
Projeto de con- \\
trole de polui- \\
çáo sonora.
\end{tabular} & \begin{tabular}{|l|} 
Exploradora re de \\
Petróleo, $\quad$ Presta- \\
dora de Serviços e, \\
Universidades.
\end{tabular} & $\begin{array}{l}\text { Regular } \\
100 \% \text { das } \\
\text { fontes em } \\
5 \text { anos. }\end{array}$ & 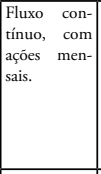 & \begin{tabular}{|l|} 
Plano de açáo: identificaçâo, \\
caracterizaçáo, quantificaçấo, \\
classificaçâo e mediçáo das \\
áreas com potencial de polui- \\
çáo sonora na área analisada. \\
\\
\end{tabular} & $\begin{array}{l}\text { Registro dos tipos poluiçáo so- } \\
\text { nora; mensuraçáo da poluiçáo } \\
\text { sonora; período de maior ocor- } \\
\text { rência; atividades, processos el } \\
\text { ou produtos geradores; área de } \\
\text { influência da geraçáo da polui- } \\
\text { çáo sonora e; técnicas adotadas } \\
\text { para controle. }\end{array}$ & 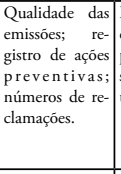 & $\begin{array}{l}\text { Exploradora } \\
\text { de petróleo, } \\
\text { prestadora de } \\
\text { serviços, e, } \\
\text { universidades. }\end{array}$ \\
\hline $\begin{array}{ll}\text { Geraçáo } & \text { de } \\
\text { semi-sólidos }\end{array}$ & $\begin{array}{l}\text { Identificar as princi- } \\
\text { pais fontes geradoras } \\
\text { de lama e cascalho na } \\
\text { área de estudo e; des- } \\
\text { tinar de maneira ade- } \\
\text { quada estes produtos. }\end{array}$ & \begin{tabular}{|l|} 
Projeto de reu- \\
so dos semi-só- \\
lidos
\end{tabular} & \begin{tabular}{|l|} 
Exploradora de \\
Petróleo, Presta- \\
dora de Serviços e, \\
Universidades. \\
\\
\\
\end{tabular} & 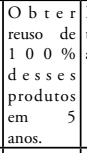 & $\begin{array}{|ll|}\text { Fluxo con- } \\
\text { tínuo, com } \\
\text { açóes diárias. } \\
\end{array}$ & \begin{tabular}{|l|} 
Determinaçáo das fontes dos \\
semissólidos; caracterizaçáo \\
fisicas, químicas e biológicas \\
dos produtos; classificaçâa, \\
separaçáo, coleta; transporte; \\
tratamento e; destinaçâo ade- \\
quada dos produtos. \\
\end{tabular} & 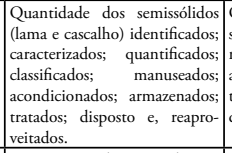 & 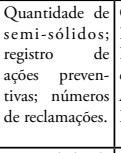 & 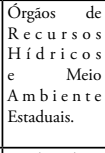 \\
\hline $\begin{array}{lr}\text { Geraçáo } & \text { de } \\
\text { resíduos } & \text { só- } \\
\text { lidos } & \end{array}$ & $\begin{array}{ll}\text { Objetiva controlar } & \text { e } \\
\text { monitorar os resíduos } \\
\text { sólidos gerados no } \\
\text { CPCA/RN. }\end{array}$ & $\begin{array}{l}\text { Projeto de ges- } \\
\text { táo de resíduos } \\
\text { sólidos }\end{array}$ & \begin{tabular}{|l|} 
Exploradorar de \\
Petróleo, Presta- \\
dora de Serviços e, \\
Universidades. \\
\\
\\
\end{tabular} & 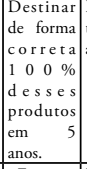 & $\begin{array}{|cc|}\text { Fluxo } & \text { con- } \\
\text { tínuo, com } \\
\text { açóes diárias. } \\
\end{array}$ & $\begin{array}{l}\text { Qualificaçáo profissional; } \\
\text { execuçáo de projetos de edu- } \\
\text { caçá em resíduos sólidos; } \\
\text { identificaçáa, classificaçá, } \\
\text { separaçáo, coleta, transporte, } \\
\text { tratamento e; destino final } \\
\text { dos resíduos. }\end{array}$ & $\begin{array}{l}\text { Quantitativo de áreas cobertas, } \\
\text { dos volumes de resíduos sólidos } \\
\text { coletados, transportados, arma- } \\
\text { zenado, tratados e destinado de } \\
\text { forma definitiva. }\end{array}$ & 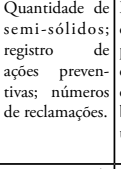 & $\begin{array}{l}\text { Exploradora } \\
\text { de petróleo, } \\
\text { prestad or a } \\
\text { de serviços, } \\
\text { órgáos am- } \\
\text { bientais e, } \\
\text { universidades. }\end{array}$ \\
\hline $\begin{array}{lr}\text { Geraçáo } & \text { de } \\
\text { emprego } & \mathrm{e} \\
\text { renda } & \end{array}$ & $\begin{array}{l}\text { Enfatiza a inclusáo } \\
\text { social de toda a popu- } \\
\text { laçáo das comunidades } \\
\text { tradicionais por meio } \\
\text { da adoçáo dos valores } \\
\text { de produçáo e cresci- } \\
\text { mento econômico. }\end{array}$ & \begin{tabular}{|c|} 
Projeto de eco- \\
nomia solidária
\end{tabular} & $\begin{array}{l}\text { Exploradora de Pe- } \\
\text { tróleo, Prestadora } \\
\text { de Serviço, ONGs } \\
\text { e, Universidades. }\end{array}$ & 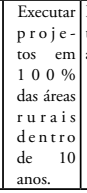 & $\begin{array}{|ll|}\text { Fluxo } & \text { con- } \\
\text { tínuo, com } \\
\text { açóes diárias. } \\
\end{array}$ & \begin{tabular}{|l|} 
Diagnóstico socioeconômi- \\
co; identificaçáo de pontos \\
fortes e fracos das comuni- \\
dades; execuçáo de açóes em \\
agricultura, gestáo de resí- \\
duos, manejo florestal, pesca \\
e, biotecnologia; qualificaçáo \\
profissional; e criaçáo de re- \\
des sociais.
\end{tabular} & $\begin{array}{l}\text { Monitorar o coeficiente de } \\
\text { atores envolvidos nos proje- } \\
\text { tos; as açós mensais e anuais } \\
\text { desenvolvidas; quantificar os } \\
\text { avanços sociais e econômicos } \\
\text { obtidos pela populaçáo local } \\
\text { e; determinar princípios, obje- } \\
\text { tivos e metas para curto, médio } \\
\text { e longo prazo. }\end{array}$ & \begin{tabular}{|l|} 
Aumento re \\
renda; numero \\
de açóes soli- \\
dárias;
\end{tabular} & $\begin{array}{l}\text { Exploradora } \\
\text { de petróleo, } \\
\text { prestadora } \\
\text { de serviços, } \\
\text { ONGs e, uni- } \\
\text { versidades. }\end{array}$ \\
\hline
\end{tabular}




\begin{tabular}{|c|c|c|c|c|c|c|c|c|c|}
\hline & \multicolumn{5}{|c|}{ PLANEJAMENTO AMBIENTAL } & \multicolumn{4}{|c|}{ GERENCIAMENTO AMBIENTAL } \\
\hline ASPECTO & OBJETIVO & AÇÁA & RESPONSÁVEL & META & PRAZO & ETAPAS & MONITORAMENTO & INDICADOR & ANÁLISE \\
\hline $\begin{array}{l}\text { Processo pro- } \\
\text { dutivo }\end{array}$ & $\begin{array}{l}\text { Objetiva a prevençáo } \\
\text { da poluiçáa; o aten- } \\
\text { dimento da legislaçáo } \\
\text { e melhoria do desem- } \\
\text { penho das atividades, } \\
\text { processos e produtos } \\
\text { executados na área. }\end{array}$ & \begin{tabular}{|l|} 
Projeto de sis- \\
tema de gestáo \\
ambiental
\end{tabular} & $\begin{array}{|lr|}\text { Exploradora } & \text { de } \\
\text { Petróleo, } & \text { Presta- } \\
\text { dora de } & \text { Serviço, } \\
\text { Consultoria } & \text { e, } \\
\text { Universidades. } & \\
& \end{array}$ & 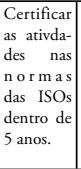 & $\begin{array}{l}\text { Fluxo con- } \\
\text { tínuo, com } \\
\text { açóes diárias. }\end{array}$ & $\begin{array}{l}\text { política ambiental; planeja- } \\
\text { mento ambiental; execução } \\
\text { da implementaçáo e opera- } \\
\text { çáo dos processos de controle } \\
\text { ambiental; avaliaçáo açóes } \\
\text { desenvolvidas e; correçáo das } \\
\text { náo conformidades. }\end{array}$ & 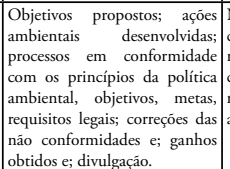 & $\begin{array}{|lr|}\text { Número re de } \\
\text { certificaçốes; } \\
\text { número de náo } \\
\text { conformidades; } \\
\text { número re de } \\
\text { açóes. }\end{array}$ & $\begin{array}{l}\text { Exploradora } \\
\text { de petróleo, } \\
\text { prestadora } \\
\text { de serviços, } \\
\text { consultorias, } \\
\text { certificadoras } \\
\text { e, universida- } \\
\text { des. }\end{array}$ \\
\hline
\end{tabular}

Dada à complexidade da problemática da atividade petrolífera no CPCA/RN os planos e programas ambientais elencados têm finalidades distintas como mitigar, monitorar, controlar, compensar ou restaurar os danos ambientais, como também ainda existem aqueles que visam potencializar os benefícios ou impactos positivos de determinadas açóes.

Diante do exposto, percebe-se que as propostas para os planos, programas e projetos foram formuladas de maneira indicativa e objetiva, no entanto para cada ação já compóem abordagem para outros trabalhos e pesquisas acadêmicas, tornando-se necessário que se aprofunde em cada assunto específico, novas investigaçóes com aplicabilidade de novas tecnologias e conhecimentos.

\section{CONSIDERAÇÓES FINAIS}

O CPCA/RN, localiza-se entre os municípios de Mossoró e Areia Branca, em uma região de enorme importância econômica, tendo em vista que são estabelecidas inúmeras atividades concomitantemente, como por exemplos, pesca, salineira, agricultura, carcinicultura, turismo, exploração de petróleo, geração de energia eólica. Ressalta ainda a relevância da área devido a proximidade com a foz do rio Apodi-Mossoró/RN, que serve como berçário para reprodução de inúmeras espécies.

Este campo petrolífero terrestre encontra-se localizado nas zonas rurais dos municípios de Mossoró e Areia Branca em uma área requerida de $362,791 \mathrm{~km}^{2}$, com uma reserva de 116 milhóes de barris de óleo, sendo explorado por 1.109 poços de petróleo e gás, através do processo produtivo: prospecção; avaliação de formação; exploração; perfuração; completação; elevação e; produção.

As atividades, processos e produtos desenvolvidos no CPCA/RN podem gerar efeitos adversos que se relacionam com os compartimentos ambientais; os aspectos sociais e; os circuitos econômicos. Com isso, as principais instabilidades são: desmatamento; supressão vegetal; afugentamento da fauna; alteração da estabilidade do ecossistema; remoção da cobertura do solo; erosão;alteração das propriedades do solo;degradação do solo;alteraçóes na dinâmica de uso e ocupação do solo; geração de lama e cascalho; geração de resíduos sólidos; geração de emissões atmosféricas; geração de ruídos; poluição sonora; geração de efluentes líquidos; derramamento de óleo; contaminação da água; alteração dos sistemas ambientais; interferência na fauna local e flora local; poluição visual e; riscos a saúde dos trabalhadores.

Para atenuar esssa problemática as instituições que atuam na região devem desenvolver açóes nos âmbitos ambientais, sociais e econômicos. Entretanto, essas medidas em sua 
maioria das vezes quando ocorrem, são com deficiência na comunicação entre as instituições, tornando-se assim, açóes pontuais, sem periodicidade, imediatista e, concentradas em determinados setores.

Nesse sentido, diante da vulnerabilidade socioambiental e econômica na área investigada faz se necessário desenvolver propostas de gestão ambiental que aborde planos, programas e projetos para a manutençáo, a prevenção, a correção e o controle das atividades, processos e produtos desenvolvidos pela atividade petrolífera da região.

Com isso, os planos, programas e projetos ambientais propostos estão organizados conformes à intervenção nos aspectos ambientais, sociais e econômicos. Para questão ambiental os planos levaram-se em consideração os compartimentos: água, solo, biota e, ar. Enquanto para o aspecto social, os programas relacionam-se com os colaboradores, a vizinhança e a sociedade. E finalmente, na variável econômica, estabeleceram-se projetos na área de formulação de novos circuitos econômicos, aprimoramento de tecnologias de exploração de petróleo e gás e, criação de tecnologias de minimização de danos ambientais.

No âmbito ambiental as ações para a área do CPCA/RN são: plano de técnicas de controle da poluição hídrica; plano de manejo e conservação do solo; plano de recuperação de áreas degradadas; plano de técnicas de prevenção e controle da erosão; plano de reflorestamento; plano de manejo animal e; plano de medidas técnicas de controle de ruídos.

Os programas sociais para regiāo do CPCA/RN são: programas de capacitação, treinamentos e capacitação dos colaboradores; programa de prevenção de riscos ambientais e; programa de educação ambiental e sanitária.

A dimensão econômica da região do CPCA/RN pode ser estimulada através de: projeto de economia solidária, projeto de reuso de efluentes industriais, projeto de reaproveitamento dos semissólidos; projeto de gerenciamento de efluentes líquidos; projeto de contingenciamento de óleo; projeto de gerenciamento de resíduos sólidos; projeto de gerenciamento de emissóes atmosféricas; projeto de inspeção veicular; projeto de controle da poluição sonora e; projeto de sistema de gestão ambiental.

Assim, a eficiência das propostas elencadas deverá ser avaliada por meio de um sistema de gerenciamento ambiental que contempla os aspectos de: etapas das ações; forma de monitoramento das açôes; indicador da eficiência das ações e; responsável pela análise das ações.

Portanto, a diminuição dos conflitos sociais, o dinamismo econômico e a manutenção da qualidade ambiental do regiâo do CPCA/RN poderá ocorrer através de planos, programas e projetos elencados que permitirá o controle da poluição ambiental; a promoção e inclusão das comunidades tradicionais e; a melhoria contínua da eficiência econômica do processo produtivo.

\section{REFERÊNCIAS}

ANP. AGÊNCIA NACIONAL DE PETRÓLEO (BRASIL). Sumário executivo do campo do amaro. Disponível em: www.anp.gov.br/?dw=8419. Acesso em: Acesso em: 25/01/2016. 
BARBOSA, C. T. P.; SOUZA NETO, J. A.; SILVA FILHO, C. A. Arsenic and antimony distribution in the stream sediments of the Canto do Amaro and Alto da Pedra Oil Fields, Northeastern, Brazil. Braziliam Journal of Petroleum and Gas, v.1, n.1, p.45-50, 2007.

CORREIA, B. R. B.; JERÔNIMO, C. E. M. Oportunidades de produção mais limpa no consumo de recursos hídricos na exploração \& produção de petróleo on shore no estado do RN. Rev. Elet. em Gestáo, Educ. e Tecnologia Ambiental, v. 7, n. 7, p. 1335-1348, 2012.

COSTA FILHO A.; BARBOSA M. P.; PETTA R. A. O uso de geotecnologias no diagnóstico de risco a desertificação no Campo Petrolífero Canto do Amaro, Município de Mossoró-RN. Engenharia Ambiental, v. 5, n. 3, p. 243-253, 2008.

COSTA FILHO A.; BARBOSA M. P.; PETTA R. A. Avaliação dos Riscos e Vulnerabilidades na Infraestrutura Exploratória no Campo Petrolífero Canto do Amaro, Município de Mossoró, RN. Engenharia Ambiental, v. 7, n. 1, p. 141-158, 2010.

COSTA FILHO A.; BARBOSA M. P.; PETTA R. A.; COSTA, A. H. A. Identificaçáo dos riscos nos processos erosivos dos rios Apodi e Mossoró no Campo Petrolífero Canto do Amaro, RN, com auxílio das imagens orbitais de alta resolução. Engenharia Ambiental, v. 6, n. 1, p. 223-230, 2009.

CONYERS, D.; HILLS, P. An introduction to development planning in the third world. New York: John Wiley \& Sons, 1984. (Public Administration in developing Countries).

CPRM. COMPANHIA DE PESQUISA DE RECURSOS MINERAIS. 2005. www. cprm.gov.br. Acesso em 20/05/2016.

DERÍSIO, J. C. Introduçáo ao controle da poluição ambiental. 4. ed. São Paulo. Editora: Oficina de Textos, 2012, 224.

FIDALGO, E.C.C. Critérios para a análise de métodos e indicadores ambientais usados na etapa de diagnóstico de planejamentos ambientais. Campinas, 2003. Tese (Doutorado Programa de Pós-graduação em Saneamento, Meio Ambiente e Recursos Hídricos) Universidade Federal de Minas Gerais.

FRANCO, M. A. R. Planejamento ambiental para a cidade sustentável. Sáo Paulo: Annablume. FAPESP, 2a Edição, 2001.

FRIEDMANN, J. Planning in the public domain: from knowledge to action. Princeton, New Jersey: Princelar University, 1987.

GIL, A.C. Como elaborar projetos de pesquisa. 4a ed. São Paulo: Atlas, 2006. 
IDEMA. INSTITUTO DE DESENVOLVIMENTO SUSTENTÁVEL E MEIO AMBIENTE. Perfil do seu município. 2008. Disponível em: <http://www.idema.rn.gov. br/perfildoseumunicipio>. Acesso: 23/04/2016.

IBGE. INSTITUTO BRASILEIRO DE GEOGRAFIA E ESTATÍSTICA. 2010. Vou te contar: a revista do censo. Disponível em: http://www.censo2010.ibge.gov.br/download/ revista/vtc14_web.pdf. Acesso em 10/01/2015.

LAGROTTI, C. A. A. Planejamento Agroambiental do Município de Santo Antônio do Jardim - SP: Estudo de caso na Micro-Bacia Hidrográfica do Córrego do Jardim. Campinas, 2000. Tese (Doutorado em Planejamento e Desenvolvimento Rural Sustentável). Universidade Estadual de Campinas, Faculdade de Engenharia Agrícola, 2000.

MEDEIROS, W.; CUNHA, L.; ALMEIDA, A. C. DE. Riscos ambientais no Litoral: estudo comparativo Brasil-Portugal. Cadernos de Geografia, n. 30/31, 2011.

MENESES, C. G.; PAULA, G. DE A. Avaliação do resíduo de cascalho de perfuração de poços de petróleo da bacia potiguar e alternativas para sua destinação e reaproveitamento. Revista Eletrônica de Petróleo e Gás, a.3, n.1, p. 29-38, 2015.

MILANI, E. J.; ARAÚJO, L. M. Recursos Minerais Energéticos: Petróleo Energy Mineral Resources: Petroleum. In: A. Bizzi, C. Schobbenhaus, R. M. Vidotti e J. H. Gonçalves (eds.) Geologia, Tectônica e Recursos Minerais do Brasil. CPRM, Brasília, 2003.

OLIVEIRA, A. A. S.; JERÔNIMO, C. E. M. Mapeamento das áreas degradadas por poços de petróleo por meio da aerofotometria na região produtora de Mossoró-RN.

Revista Eletrônica em Gestáo, Educação e Tecnologia Ambiental, v. 18, n. 1, p.648651, 2014.

OLIVEIRA, R. C.; SANTOS, J. B. Gestão ambiental nas empresas do setor de petróleo e gás em Mossoró-RN. Holos, v. 3, 2007.

PETTA R. A.; CAMPOS, T.F.C. Estimativa da Radioatividade Regional nas Instalaçóes Petrolíferas e Industriais do Canto do Amaro (RN). Revista de Geologia, v. 26, n. 2, p. 35-44, 2013.

PORTAL BRASIL. Produção de Petróleo fica Acima de 2,2 Milhóes de Barris/dia pelo Terceiro mês Consecutivo. Editorial, 10/04/2012. Disponível em: < http://www.brasil. gov.br/noticias/arquivos/2012/04/10/producao-de-petroleo-ficaacimade-2-2-milhoes-debarris-dia-pelo-terceiro-mes-consecutivo > Acesso em 07/08/2015.

PORTO, M. F. de S.; SCHUTZ, G. E. Gestão ambiental e democracia: análise crítica, cenários e desafios. Ciência e Saúde Coletiva, v. 17, n. 6, 2012. 
SÁNCHEZ, L. E. Avaliação de Impactos Ambientais: conceitos e métodos. 2 ed. São Paulo: Oficina de Textos, 2012.

SANTOS, R. F. Planejamento Ambiental: teoria e prática. São Paulo: Editora Oficina de Textos, 2004.

SANTOS, R. F.; PIVELLO, V. R. Planejamento Ambiental. Apostila do Curso Planejamento Ambiental - IC - 755 - UNICAMP, 1998.

SLOCOMBE, D. S. Environmental planning, ecossystem Science and ecosystem approaches integrating environment and development. In. Environmental Management. New York, v. 17, n. 03., 1993.

THOMAS, J. E. (Org.). Fundamentos de engenharia do petróleo. 2a. Ed. Rio de Janeiro: Interciência: Petrobrás, 2004.

YOUNG, A. F. Qualidade ambiental em micro-bacias urbanas - rurais: um estudo comparado entre as bacias Ribeirão das Cabras e Piracicamirim. Campinas, 2000. Dissertaçáo (Mestrado em Planejamento e Desenvolvimento Rural Sustentável). Universidade Estadual de Campinas, Faculdade de Engenharia Agrícola, 2000. 